\title{
Review
}

\section{Fatty acid metabolism and insulin secretion in pancreatic beta cells}

\author{
G. C. Yaney, B. E. Corkey \\ Boston University School of Medicine, Obesity Research Center, Boston, USA
}

\begin{abstract}
Increases in glucose or fatty acids affect metabolism via changes in long-chain acyl-CoA formation and chronically elevated fatty acids increase total cellular CoA. Understanding the response of pancreatic beta cells to increased amounts of fuel and the role that altered insulin secretion plays in the development and maintenance of obesity and Type 2 diabetes is important. Data indicate that the activated form of fatty acids acts as an effector molecule in stimulus-secretion coupling. Glucose increases cytosolic long-chain acylCoA because it increases the "switch" compound malonyl-CoA that blocks mitochondrial $\beta$-oxidation, thus implementing a shift from fatty acid to glucose oxidation. We present arguments in support of the following: (i) A source of fatty acid either exogenous or endogenous (derived by lipolysis of triglyceride) is necessary to support normal insulin secretion; (ii) a rapid increase of fatty acids potentiates glucose-stimulated
\end{abstract}

secretion by increasing fatty acyl-CoA or complex lipid concentrations that act distally by modulating key enzymes such as protein kinase $\mathrm{C}$ or the exocytotic machinery; (iii) a chronic increase of fatty acids enhances basal secretion by the same mechanism, but promotes obesity and a diminished response to stimulatory glucose; (iv) agents which raise cAMP act as incretins, at least in part, by stimulating lipolysis via beta-cell hormone-sensitive lipase activation. Furthermore, increased triglyceride stores can give higher rates of lipolysis and thus influence both basal and stimulated insulin secretion. These points highlight the important roles of NEFA, LC-CoA, and their esterified derivatives in affecting insulin secretion in both normal and pathological states. [Diabetologia (2003) 46:1297-1312]

Keywords Insulin secretion, fatty acid, malonyl-CoA, long-chain acyl-CoA, incretin, hormone sensitive lipase, protein kinase $\mathrm{C}$, exocytosis, acylation, metabolism.
Received: 14 April 2003 / Revised: 14 July 2003

Published online: 12 September 2003

C) Springer-Verlag 2003

Corresponding author: Dr. B. E. Corkey, Boston University School of Medicine, Obesity Research Center, EBRC 804, 650 Albany Street, Boston, MA 02118, USA

E-mail: bcorkey@bu.edu

Abbreviations: ACS, acyl-CoA synthetase; ACC, acetyl-CoA carboxylase; BAT, brown adipose tissue; CPT, carnitine palmitoyl transferase; CL, citrate lyase; DAG, diacylglycerol; GSIS, glucose-stimulated insulin secretion; HSL, hormone-sensitive lipase; $\mathrm{K}_{\mathrm{ATP}}$, ATP-sensitive $\mathrm{K}^{+}$channel; LC-CoA, long chain acylCoA; PA, phosphatidate; PFK-1, phosphofructokinase-1; PKC, protein kinase C; PMA, phorbol myristate acetate; $\mathrm{PC}$, pyruvate carboxylase; PS, phosphatidylserine; SNAP, soluble NSF-associated protein; SNAP-25, synaptosomal-associated protein of 25 $\mathrm{kD}$; t-SNARE, target SNAP receptor; v-SNARE, vesicle SNAP receptor; VAMP, vesicle-associated membrane protein; VDCC, voltage-dependent $\mathrm{Ca}^{2+}$ channel; WAT, white adipose tissue.

\section{Introduction}

Type 2 diabetes, which accounts for 90 to $95 \%$ of diabetes worldwide, and obesity are prevalent and expensive diseases in Western society. Diabetes is estimated to affect $6 \%$ of the adult population and with a growth rate of $6 \%$ per annum, it is estimated that 200 to 300 million people will be afflicted by the end of the decade [1]. As obesity is the single most important risk factor for Type 2 diabetes, its rapid increase could well be driving this growth.

These diseases share two characteristics. First, insulin resistance is a characteristic of almost all people with Type 2 diabetes or obesity. In most cases of early diabetes and obesity, insulin concentrations are either normal or greatly increased. Obesity, with accompanying insulin resistance, is a powerful risk factor for 
Type 2 diabetes. Furthermore, obesity and insulin resistance are found in people who are at an increased risk for developing these disorders, suggesting that they could be common pathological factors, or at least early events in their development. Second, obesity and Type 2 diabetes are often associated with hypertriglyceridaemia or increased circulating concentrations of NEFA [2, 3]. Therefore Type 2 diabetes can also be considered a lipid disorder as well as a disease of glucose tolerance [4] and it is possible that increased circulating lipid concentrations explain, at least in part, not only insulin resistance but also betacell dysfunction in Type 2 diabetes.

\section{A role for the beta cell in Type 2 diabetes and obesity}

Beta cells are involved in the abnormalities associated with both obesity and Type 2 diabetes. It has long been appreciated that obese humans and experimental animal models are hyperinsulinaemic and insulin resistant [5]. The development of obesity with the progression to Type 2 diabetes often involves a high-fat, high-sucrose diet. Under these conditions insulin secretion increases to accommodate the need to store glucose and excess fatty acids. The islet lesion in obesity is basal hypersecretion. In Type 2 diabetes, which can also involve basal hypersecretion, the main betacell lesion is a defect in the ability of glucose to incrementally stimulate insulin release. In addition, there is a reduction in the potentiating action of other substrates, such as amino acids or fatty acids, hormones or neuronal factors, in interacting with glucose to further stimulate secretion [6]. We propose that these lesions occur in susceptible people in whom the signal transduction enzymes, such as protein kinases, exhibit altered sensitivity to conditions that regulate longchain acyl CoA (LC-CoA), the metabolically active form of long-chain fatty acids. Thus, obesity could be the initial condition which sets up the chain of events, with a subset of subjects in this pool developing Type 2 diabetes. If the beta cell lesion is prompted by both high fatty acids concentrations and high glucose, then an even smaller subset of lean subjects should develop Type 2 diabetes.

\section{A role for adipocytes in Type 2 diabetes and the control of insulin release}

The adipocyte is the main storage depot for triglycerides in the body. Stimulation of $\beta 1$ and $\beta 3$ adrenergic receptors found on white adipose tissue (WAT) and brown adipose tissue (BAT) activates hormone-sensitive lipase (HSL), causing lipolysis, the release of NEFA and a reduction of fat stores with an improvement of obesity-induced insulin resistance [7]. The $\beta 3$-ad- renergic receptor, which is predominately expressed on WAT and BAT, represents a potential anti-obesity target for drug treatment and for which several selective agonists have been developed $[8,9]$.

Short term treatment of rodents with such an agonist, CL 316,243, resulted in a twofold increase in energy expenditure as measured by $\mathrm{O}_{2}$ consumption, a $50 \%$ reduction in food intake, and a rapid fourfold increase in serum NEFA that peaks within 5 min. Most striking, however, was a 50- to 100 -fold increase in serum insulin concentrations that peak within $10 \mathrm{~min}$ $[10,11,12]$. Use of $\beta 3$-receptor knockout mice showed that these effects are mediated exclusively by the expression of this receptor on fat cells. Re-expression of the $\beta 3$-receptor in WAT completely restored the effect on serum NEFA concentrations and the dramatic rise in serum insulin concentrations [13]. In contrast, re-expression of the $\beta 3$-receptor in BAT had the effect of only partially restoring the increase in $\mathrm{O}_{2}$ consumption.

The fivefold increase in NEFA followed by a 50- to 100 -fold increase in serum insulin shows that the hypothesized link from adipose to islet tissues is important. Given the rapidity and magnitude of this response an increase in hepatic glucose production or a reduction in insulin clearance can be ruled out. Thus, adipocyte products could play a major role in regulating insulin secretion in vivo. These products include, but might not be limited to NEFA or could depend on the physiological mix of NEFA contained in the adipocyte. Whether other products released from WAT with $\beta 3$-receptor stimulation, in addition to NEFA, are acting directly on the beta cell remains to be determined.

\section{Metabolism in beta cell stimulus-secretion coupling}

High-energy intermediates. The molecular mechanism by which glucose and other fuels stimulate insulin release is still unclear. Fuel-induced secretion, like other regulated secretory processes, is dependent on extracellular free $\mathrm{Ca}^{2+}$. However, beta cells possess a unique stimulus-response coupling system, which requires that the fuel stimulus be metabolized to initiate membrane electrical events, which lead to cell depolarization and secretion $[14,15]$. Only fuels that stimulate insulin secretion stimulate change in electrical activity. Inhibition of fuel metabolism inhibits both secretion and electrical activity $[14,16]$. Metabolism of glucose generates signals that modulate the activities of enzymes and ion channels, increasing the concentrations of intracellular messengers $[17,18]$. These include high-energy intermediates and also adenine nucleotides $[19,20,21]$, pyridine nucleotides [22, 23], and $\mathrm{CoA}$ derivatives [24, 25]. Among the latter is malonyl-CoA, an inhibitor of carnitine palmitoyl transferase (CPT)-1 that could cause a switch from 
fatty acid oxidation to complex lipid formation. It should be noted that only fuels or fuel combinations that elevate malonyl-CoA stimulate secretion [25] and that inhibition of malonyl-CoA production inhibits secretion [26]. Glucose-stimulated insulin secretion (GSIS) is associated with inhibition of NEFA oxidation and increased lipid synthesis in pancreatic beta cells $[24,27,28,29]$. Indeed, significant increases occur in the total mass of diacylglycerol (DAG) [30] and phosphatidate (PA) [18] in glucose-stimulated beta cells. Glucose and endogenous LC-CoA are the main sources of the glycerol and lipid components, respectively, of DAG and PA [28, 30]. In addition, exogenous fatty acids potentiate GSIS [25, 29, 31], possibly by providing additional acyl groups for LC-CoA formation or the synthesis of complex lipids.

Anaplerosis and cataplerosis. Accelerated acetyl-CoA production is undoubtedly essential for the rapid generation of reducing equivalents and ATP, and consequently for ATP-sensitive $\mathrm{K}^{+}\left(\mathrm{K}_{\mathrm{ATP}}\right)$ channel closure. It is however not sufficient since substrates which are metabolized directly to acetyl-CoA, i.e. fatty acids and ketone bodies, are not secretagogues in the absence of glucose [32]. Thus, accelerated production of acetylCoA and oxidative events do not solely account for full induction of insulin secretion. However, anaplerosis is likely to be important in beta-cell activation for several reasons. Firstly, it is required for the efficient operation of either a pyruvate/malate or pyruvate/citrate shuttle allowing the production of cytosolic malonyl-CoA [32] and NADPH [33]. Approximately 40\% of the glucose carbon entering the citric acid cycle is carboxylated in rat islets [34]. This is a very high percentage for a non-gluconeogenic tissue [35] and a cell synthesizing fatty acids at a low rate [36]. Secondly, the dose dependencies of anaplerosis, citrate, malate and malonyl-CoA accumulation in response to glucose correlate well with secretion in beta cells [37, 38]. Thirdly, methylsuccinate is a potent secretagogue in intact beta cells [39] and succinate directly promotes exocytotic release of insulin in permeabilized pancreatic beta cells [40]. Fourthly, phenylacetic acid reduces anaplerosis and insulin secretion in clonal beta cells (INS) and rat islets [37] by inhibition of pyruvate carboxylate.

Thus, glucose, glyceraldehyde and dihydroxyacetone, which feed directly into glycolysis are all secretagogues [14]. After their transformation to pyruvate they can be metabolized to both acetyl-CoA and oxaloacetate directly. However, glucose which provides anaplerosis is required for fatty acid- and ketone body-induced insulin release [41, 42]. Leucine (acetyl-CoA production) and glutamine (anaplerosis) synergize to promote secretion [42]. These features of beta-cell fuel stimuli favour the concept that acetyl-CoA production and anaplerosis are the earliest mitochondrial events synergizing to promote the production of coupling factors activating the beta-cell secretory process and is consistent with the idea that changes in lipid partitioning also play a key role in the regulation of insulin secretion $[43,44]$.

\section{$K_{\text {ATP }}$ channel-dependent and -independent actions of glucose}

The consensus model of nutrient-stimulated secretion postulates that increased glycolysis and respiration due to glucose metabolism leads to accelerated ATP production and an increase in the ATP to ADP ratio [44]. This in turn closes the $\mathrm{K}_{\mathrm{ATP}}$ channel, depolarizes the cell, increases the open time of voltage-dependent $\mathrm{Ca}^{2+}$ channels and raises intracellular $\mathrm{Ca}^{2+}$. The increased $\mathrm{Ca}^{2+}$ then modulates kinases or other effector systems involved in secretion. The broad outlines of the $\mathrm{K}_{\text {ATP }}$ channel-dependent pathway described above are fairly well worked out as several components have been cloned [45, 46, 47]. However, this model does not prove entirely satisfactory given that $\mathrm{K}^{+}$-induced secretion, which maximally increases $\mathrm{Ca}^{2+}$, only transiently stimulates secretion [14]. In addition, recent reports have documented GSIS which is independent of the $\mathrm{K}_{\text {ATP }}$ channel $[48,49,50]$. This stimulation is dependent on glucose metabolism, has a normal concentration dependence, is shared by other nutrients, and is either independent of $\mathrm{Ca}^{2+}$ [50] or changes in $\mathrm{Ca}^{2+}[48,51]$. In addition, the action of glucose in the absence of $\mathrm{Ca}^{2+}$ can be mimicked by long-chain fatty acids provided that activators of protein kinase $\mathrm{C}$ and protein kinase A are present [52]. This is consistent with the notion that both glucose and NEFA are signalling through cytosolic LC-CoA.

A more inclusive model of nutrient-stimulated secretion involves two arms of signal transduction which occur simultaneously (Fig. 1). One arm is de-

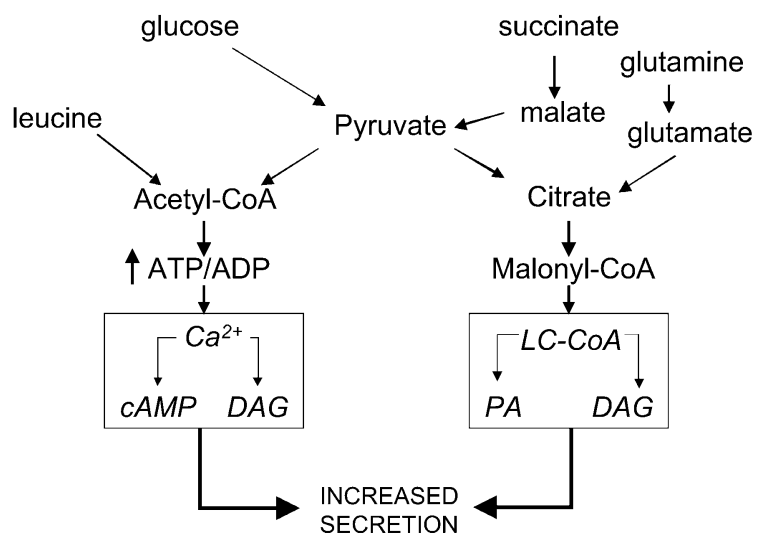

Fig. 1. Proposed dual signalling pathways involved in the physiological stimulation of insulin secretion by nutrients. The primary $\left(\mathrm{Ca}^{2+}\right.$ and LC-CoA) and secondary (cAMP, DAG and PA) intracellular messengers generated in each pathway are shown boxed 
pendent upon modulation of the $\mathrm{K}_{\mathrm{ATP}}$ channel evoked by changes in the ATP:ADP ratio due to glycolysis and the accelerated production of acetyl-CoA. Secretory input from this arm would be an increase in cytosolic $\mathrm{Ca}^{2+}$ and secondary to this, changes in cAMP and products of phospholipase activation such as DAG. The other arm is dependent upon anaplerotic input into the TCA cycle, generation of excess citrate with its accumulation in the cytosol, and increases in cytosolic malonyl-CoA $[44,53]$. Secretory input from this arm would be increased cytosolic malonyl-CoA and LC-CoA, and secondary to this, the increased synthesis of complex lipids such as PA and DAG. This is consistent with the ability of hydroxycitrate to prevent the rise in cytosolic LC-CoA by blocking malonylCoA production and thus inhibiting nutrient-stimulated insulin secretion [26]. This inhibition can be overcome by the addition of exogenous NEFA. Complementing this result is the finding that expression of a dominant negative form of acetyl $\mathrm{CoA}$ carboxylase (ACC), the key enzyme in the synthesis of malonylCoA, prevents its rise and also inhibits secretion [54]. Thus, the model predicts that signalling through both arms would be required for a normal secretory response to nutrients. Other nutrient secretagogues also fit this model. Methylsuccinate which is converted to succinate in the cytosol enters the mitochondria in exchange for malate. In turn, malate is converted to pyruvate in the cytosol by malic enzyme which then follows the same metabolic route as pyruvate derived from glucose (Fig. 1).

\section{Oscillations in insulin secretion}

Insulin secretion is normally oscillatory in vivo, in isolated islets and clonal beta cells [55]. The physiological importance of insulin oscillations for beta-cell function is suggested by their loss or impairment in Type 2 diabetic patients and their near relatives [56, 57]. Since oscillations increase the potency of insulin on target tissues, the loss of oscillations could contribute to an insufficient pattern of insulin production that leads to diabetes. Metabolites that have been measured at sufficiently frequent intervals also oscillate in beta cells, such as the ATP:ADP ratio [58, 59]. We have suggested that this pattern could be crucial for generating the wide swings in signals required for metabolism-secretion coupling. Such high and low values would also help to explain how both the ATP:ADP ratio and $\mathrm{O}_{2}$ consumption show average increases in stimulated beta cells, despite the well established observation that an increase in the ATP:ADP ratio inhibits $\mathrm{O}_{2}$ consumption [60]. Oscillations would also prevent the continuous increase of stimulatory metabolites which would probably lead to desensitization and down-regulation of responses. Our concept of the mechanism of the metabolic oscillations is based on detailed studies of spontaneous oscillatory glycolysis in skeletal muscle extracts [55]. These oscillations are driven by autocatalytic activation of the muscle isoform of the key glycolytic enzyme phosphofructokinase-1 (PFK-1) by its product fructose 1,6-bisphosphate resulting in large oscillations in the ATP:ADP ratio. The muscle isoform of this enzyme, PFK-M, has recently been shown to be the dominant PFK activity in beta cells [61].

Our previous work has established that the time course of changes in metabolic and ion parameters such as changes in the ATP:ADP ratio or in metabolites such as malonyl-CoA occur before increases in $\mathrm{Ca}^{2+}$ or insulin secretion [58, 62]. This might allow for complex regulation of various targets dependent on the phasing of such oscillations. For example, it could be important for the peak of the ATP:ADP ratio to coincide with the trough of the LC-CoA concentration since these two metabolites have opposite effects on the $\mathrm{K}_{\text {АTP }}$ channel $[63,64,65,66]$.

\section{NEFA metabolism in the beta cell}

Fatty acids, not glucose, are believed to be the major endogenous energy source for unstimulated islets [67]. This is consistent with the observations that islets maintain high rates of oxygen consumption in the absence of exogenous fuels but contain little glycogen [68]. Stimulation of islets by glucose diminishes fatty acid oxidation and increases total respiration [27, 28, 29]. Thus, glucose stimulation seems to shift the beta cell from fatty acids to glucose as an oxidative fuel. This occurs through glucose conversion to malonyl-CoA, which inhibits CPT- 1 and thus blocks LC-CoA oxidation by preventing transport into the mitochondria [32]. Glucose causes marked alterations in the acyl-CoA profile of clonal pancreatic beta cells, with the largest (fivefold) and earliest (by $2 \mathrm{~min}$ ) change occurring in malonyl-CoA [24, 25]. There is a tighter correlation between secretion and LC-CoA concentrations than between secretion and malonyl-CoA concentrations. This observation coupled with the fact that de novo fatty-acid synthesis is very low in the beta cell [27] indicates that malonylCoA is used as a "switch" compound not as a precursor or effector molecule like LC-CoA. Inhibition of mitochondrial NEFA (LC-CoA) oxidation increases LC-CoA in the cytosol and could explain the observed increases in de novo synthesis of DAG and phospholipids after stimulation. The increases in LCCoA, PA and DAG resulting from glucose stimulation could directly activate protein kinase $\mathrm{C}$ (PKC) isoforms [31] or modify the acylation state of key proteins involved in regulating ion-channel activity and exocytosis [69].

Multiple steps are involved in controlling cytosolic LC-CoA concentrations (Fig. 2). Long-chain NEFA 


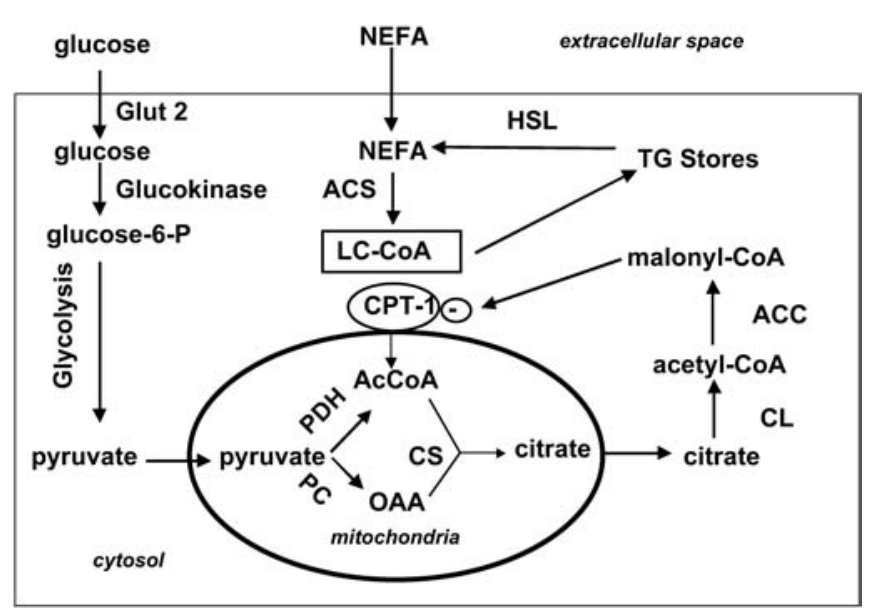

Fig. 2. Fatty acid metabolism in the pancreatic beta cell. Pathways for the formation of cytosolic LC-CoA stemming from the metabolism of glucose and either exogenous or endogenously generated free fatty acids are illustrated. HSL hormone sensitive lipase, $T G$ triglyceride, $L C$-CoA long-chain acylCoA, ACS acyl-CoA synthetase, $P C$ pyruvate carboxylate, $P D H$ pyruvate dehydrogenase, $C S$ citrate synthese, $C L$ citrate lyase, $A C C$ acetyl-CoA carboxylase

seems to be exclusively transported into the cell by free diffusion with no obvious requirement for active transport [70]. The very high avidity with which NEFA partition into phospholipid membranes makes it almost impossible for transport proteins to compete with the very rapid physical "flip-flop" that has been documented. The model predicts that even at NEFA concentration as low as $2 \mathrm{nmol} / \mathrm{l}$ in the aqueous phase, the concentration in the bilayer is $2 \mathrm{mmol} / \mathrm{l}$ or $2 \mathrm{~mol} \%$ relative to phospholipids, thus allowing for large transmembrane fluxes. For these reasons, extracellular NEFA can be expected to rapidly distribute in the available lipid bilayers and to move rapidly from cell to cell, potentially acting as paracrine mediators. In addition, islets express low-density lipoprotein receptors [71] and lipoprotein lipase [72] and could also obtain fatty acids from circulating lipoproteins.

The first step in the control of NEFA partitioning is substrate supply. In the resting state, when glucose is low, fatty acids are converted to LC-CoA by acyl-CoA synthetase (ACS) and enter the mitochondria where they are oxidized via the $\beta$-oxidation pathway for the energy production needed [28]. The shift from NEFA to glucose as an oxidative fuel occurs through glucose conversion to the "switch" compound malonyl-CoA. This compound in turn inhibits CPT-1, found on the outer mitochondrial membrane, and thus blocks LCCoA entry into the mitochondria [73]. Cytosolic concentrations of LC-CoA esters are controlled by feedback inhibition of ACS and are buffered by fatty acid and LC-CoA-binding proteins [74]. The total CoA pool is fixed over short periods of time and distributed unevenly between cytosolic and mitochondrial pools which are not interchangeable [75]. Thus, the maxi- mal LC-CoA concentration is limited by the total CoA pool and by the compartmental distribution. There is a reciprocal relationship between these two pools, such that when transport into the mitochondria is limited, the concentration in the cytosol should increase. In response to CPT-1 inhibition, measured changes in total cellular LC-CoA can increase or decease depending on the percentage of the total made up by the mitochondria, which tend to contain the higher concentration. However, short term increases in extracellular NEFA might increase LC-CoA in both compartments. In addition, increased serum NEFA or certain drugs or steroids can increase the total CoA pool over the course of hours to days [76]. The cytosolic free concentration of LC-CoA is not known in any cell, but the total concentration has been calculated to be 95 and $220 \mathrm{nmol} / \mathrm{g}$ dry weight in livers of fed and fasted rats, respectively [76]. Based on Scatchard analysis of palmitoyl-CoA binding in permeabilized beta cells, the half-maximal cytosolic concentration in beta cells is estimated to be about $1 \mu \mathrm{mol} / \mathrm{l}$, suggesting that this is the resting free concentration and the balance is bound to proteins or membranes [77].

\section{Potentiation of GSIS by extracellular NEFA}

The rapid effect of NEFA to potentiate GSIS in vitro, while having little effect on secretion at non-stimulatory glucose concentrations, would suggest that they act as incretins $[25,31,78,79,80]$. This effect has also been documented in vivo, where NEFA increase serum insulin concentrations in animals [81] and humans [82]. Under normal physiologic conditions the necessity for simulatory glucose can stem from the additional need for one or more of the following signals generated by glucose: (i) an increased influx of $\mathrm{Ca}^{2+}$, (ii) an increased ATP:ADP ratio acting distal to the $\mathrm{K}_{\text {ATP }}$ channel, (iii) increased production of $\alpha$-glycerol phosphate as a precursor to complex lipids, or (iv) increased malonyl-CoA required for inhibition of CPT1. The observations that palmitate is both oxidized $[28,83]$ and also results in increases in cytosolic $\mathrm{Ca}^{2+}$ $[78,84]$ suggest glucose-like actions in stimulating secretion. Another possibility is that the LC-CoA derivative of the fatty acid directly modulates multiple effector systems in stimulating secretion $[31,63,69,77$, $85]$ or that its esterification into complex lipids provides the necessary signalling factors in potentiating secretion [29, 78, 83, 86, 87, 88]. Several descriptive studies dealing with extracellular NEFA have shown that an increase in chain length, peaking around C16, and increasing saturation correlates with an increase in insulinotropic action of NEFA [80, 89, 90].

The requirement for circulating NEFA in maintaining the response of the pancreas after a fast highlights the physiological significance of this interaction [90, 91, 92]. These studies extended our understanding of 
chain length and saturation in modulating the potentiation of glucose as well as suggesting that the specific mixture of NEFA is also important. It was hypothesized that for a given concentration of glucose the response of the pancreas is regulated not only by the concentration of NEFA, but also by the composition of this pool. In more recent work these findings included not only GSIS but also insulin secretion stimulated by amino acids and $\mathrm{KCl}$-induced depolarization, suggesting that a critically important fatty acid-dependent step exists late in the stimulus-secretion coupling pathway [86]. The nature of this lipid-derived factor, its site or mechanism of action are not known. Interestingly, work in a HSL knockout mouse shows a requirement for lipolysis in nutrient-stimulated insulin secretion [93]. Findings showing that palmitate and myristate can substitute for glucose in augmenting the $\mathrm{Ca}^{2+}$-independent pathway of secretion in islets [52] and could involve protein acylation [94] are consistent with this conclusion.

\section{The beta cell response to hyperlipidaemia}

NEFA have very different effects on insulin secretion depending on the specific NEFA and the length of time of exposure [95]. Short-term exposure of islets or beta cells to saturated long-chain NEFA provide a powerful potentiation of GSIS, whereas long-term exposure results in increased basal secretion and a blunted response to glucose. This dichotomy in response has been shown both in vitro $[26,89]$ and in vivo [81, 82, 96]. At early time points after lipid infusion $(<6 \mathrm{~h})$, glucose-stimulated secretion in these studies is enhanced, whereas measurements at 24 and $48 \mathrm{~h}$ show mostly an inhibition. Studies in vivo using heparin and lipid infusion do not always show inhibition at longer time points. A recent study [97] shows that long-term exposure to saturated NEFA results in enhanced GSIS, with the development of insulin resistance. However, unsaturated NEFA exposure results in impaired GSIS without insulin resistance. Epidemiological evidence links the ingestion of saturated NEFA with hyperinsulinaemia and insulin resistance [98].

These opposite effects of NEFA can be explained by: (i) desensitization of pathways due to continuous stimulation; (ii) the presence in the cell of enzymes with different concentration dependencies for regulation by LC-CoA, that are either stimulated, e.g., PKC [31], or inhibited e.g., PKC [31, 99], the adenine nucleotide translocase [100] and glucokinase [101]; and (iii) the ability of NEFA or LC-CoA to alter gene expression $[102,103]$. Therefore, it is predicted that the response to NEFA or the resulting increase in cytosolic LC-CoA will depend on the concentration achieved and the length of time of the exposure. Accordingly, it can be hypothesized that hyperlipidaemia and increased NEFA are causally implicated in the progres- sive alteration in glucose metabolism in pancreatic beta cells and could explain the glucose recognition defect of islet tissue in subjects with Type 2 diabetes. The effect seen in isolated islets with chronic fatty-acid treatment causing a left shift in the glucose dose response curve, basal hyper-secretion and diminished stimulation by glucose, could involve increased activity of hexokinase, due to a rise in maximal activity and deinhibition by lowered glucose 6-phosphate concentrations [104]. The drop in glucose 6-phosphate in turn is most likely a result of increased PFK activity, caused by a rise in maximal activity and decreased concentrations of the inhibitor citrate because of decreased citrate synthase activity [104]. Abnormal sensitivity to glucose also results from chronic exposure to increased concentrations of glucose [53]. Decreased insulin secretion in response to glucose is preceded by enhanced sensitivity to glucose in the partially pancreatectomized model; this could be due to an increase of LC-CoA and products formed from LC-CoA, caused by glucose through the production of malonyl-CoA [24]. Thus, both hyperlipidaemia and hyperglycaemia probably cause an increase in cytosolic LC-CoA but by different mechanisms.

Chronic exposure of the beta cell to increased concentrations of NEFA inhibits insulin secretion [102] and biosynthesis [106], the expression of the beta cell transcription factor PDX-1 [107], the Glut-2 glucose transporter [107], ACC [102] while increasing CPT-I expression [103]. Thus, beta cell "glucolipoxia" probably plays an important role in the causes of obesityassociated Type 2 diabetes [32]. Within the framework of this hypothesis, alterations in malonyl-CoA production and in the expression of enzymes controlling lipid partitioning (ACC, CPT-I, HSL, and others) play important roles.

\section{Hormone-sensitive lipase and lipid signalling in the beta cell and adipose tissue}

Another source of NEFA available to raise beta cell cytosolic LC-CoA is its own triglyceride stores. Hormone-sensitive lipase (HSL) is a unique fatty acyl hydrolase expressed in the key tissues of insulin production and action: the pancreatic beta cell [108, 109, 110], the adipocyte [111] and skeletal muscle [111]. New evidence suggests that HSL, the rate-limiting step in triglyceride hydrolysis, plays a pivotal role in energy homeostasis via its roles in fat cells and beta cells [93, 112]. Consistent with this finding, HSLknockout mice show reduced GSIS both in vivo and in isolated islets. These data provide important evidence that NEFA, their CoA derivatives or complex lipids formed from them are critical coupling factors in nutrient signalling in the beta cell. Recent evidence indicates that lipolysis of beta-cell triglyceride stores could play a central role in the action of incretins such 
as GLP-1 in potentiating GSIS via increased intracellular cAMP $[113,114]$.

HSL transcripts have been studied in fat, testicle and beta cells [111]. The regulation of HSL transcription has mainly been studied in fat, where it is increased with fasting and diabetes [111]. Increased glucose induces the HSL gene in the beta cell with a resulting twofold increase in HSL protein and enzymatic activity [110]. This is associated with high basal secretion [53] in accordance with the view that lipid signalling molecules are implicated in glucose-stimulated secretion [110, 113]. Although HSL transcription is controlled, most of the regulation of its activity in adipocytes seems to be post-translational. $\beta$-Adrenergic stimulation of adipocytes results in the PKA-mediated phosphorylation of HSL and perilipin, the protein that coats the lipid droplets in the basal state. Following this phosphorylation, HSL translocates from the cytoplasm to the surface of the lipid droplet, while perilipin shifts in the opposite direction [111]. The relative importance of HSL and perilipin in this process is not completely established but both appear to be essential.

HSL is a fatty acyl hydrolase that is promiscuous in its range of substrates, cleaving DAG, triglycerides and to a minor degree, $\mathrm{MG}$, as well as fatty acyl esters of cholesterol, steroid hormones and retinoic acid [111]. The greater activity against DAG than triglyceride is notable and could explain the marked increase of DAG in several tissues of HSL-deficient mice [115]. However, the great number of substrates and products of HSL implies that a number of compounds and pathways must be considered as mediators for the pathogenic mechanisms of HSL deficiency.

\section{Potential mediators and targets of LC-CoA esters}

LC-CoA or products derived from them, such as complex lipids, are potent regulators of enzymes, ion channels and various signal transducing effectors in many cell types (Table 1). These targets include the adenine nucleotide translocase, CPT-1, the tricarboxylic acid carrier, the nuclear thyroid hormone receptor,

Table 1. Potential mediators and targets of LC-CoA

\begin{tabular}{ll}
\hline LC-CoA targets & Acylation targets \\
\hline PKC & SNAP-25 \\
Ca $^{2+}$ ATPase & VAMP \\
Adenine Nucleotide Transferase & Synaptotagmin \\
CPT-1 & CSP \\
HSL & VDCC ( $\beta$-subunit) \\
K $^{+}$-ATP Channel & PKC \\
\hline
\end{tabular}

Beta-cell proteins and effector systems affected by LC-CoA either through their binding or acylation are listed. PKC, protein kinase C; HSL, hormone-sensitive lipase; CSP, cysteine string protein
$\mathrm{K}^{+}{ }_{\text {ATP }}$ channel, and several ATPases [116]. Of particular interest in this context, LC-CoA esters modulate the activity of proteins that contain adenine or guanine nucleotide binding sites, possibly as a consequence of the similarities in structure with coenzyme A [32]. NEFA, possibly via LC-CoA and/or complex lipid production are essential for insulin secretion in response to both fuel and non-fuel stimuli [86]. For instance, lysophosphatidate and PA might act as betacell signalling molecules. Lysophosphatidate, which potently promotes insulin release in rat islets [117] is the first phospholipid synthesized from LC-CoA, the precursor of many signalling phospholipids and an established signalling molecule [118, 119].

Five non-exclusive potential targets could be involved in the modulation of GSIS by fatty acids: (i) LC-CoA, either directly or indirectly via DAG production could activate $\mathrm{C}$-kinase enzymes [31, 43]; (ii) a rise in cytosolic LC-CoA could directly cause the exocytotic release of insulin [69]; (iii) LC-CoA could modulate $\mathrm{K}_{\mathrm{ATP}}$ channel activity directly or via complex lipid formation. Thus, various lysophospholipids [120] and phosphoinositide [121] are potent inhibitors of beta cell $\mathrm{K}_{\mathrm{ATP}}$ channels whereas LC-CoA increases the open-state probability of $\mathrm{K}_{\text {ATP }}$ channels in the beta cell $[63,64,65,66]$. (iv) Stimulation of $\mathrm{Ca}^{2+}$-ATPases by increases in cytosolic LCCoA has been observed in clonal beta cells [77]. (v) Inhibition of HSL or other lipase activity is observed with increases in cytosolic LC-CoA [116, 122].

Of these targets, the action of LC-CoA on two would be predicted to be a net positive for insulin secretion: stimulation of various PKC isoforms, and direct stimulation of exocytosis. These positive actions seem to be the dominant effects, as indicated by the immediate stimulatory effect of exogenous NEFA on glucose-stimulated insulin secretion. In contrast, activation of either $\mathrm{K}_{\mathrm{ATP}}$ channels or $\mathrm{Ca}^{2+}$-ATPases would be expected to inhibit secretion by lowering cytosolic $\mathrm{Ca}^{2+}$ by different mechanisms. However, it is not clear whether the negative-feedback inhibition of HSL in either the beta cell or the adipocyte after a rise in serum NEFA concentrations would affect secretion. These latter negative effects might simply be quantitatively unimportant or less important under physiological conditions. Another intriguing possibility is that in the context of oscillations in glycolysis, intracellular $\mathrm{Ca}^{2+}$ and secretion $[59,114,123,124,125,126]$, they may actually contribute to the recovery of resting cytosolic $\mathrm{Ca}^{2+}$ after its increase, if LC-CoA oscillates out of phase with the ATP:ADP ratio. This scenario would be distinct from the incretin effects of exogenous NEFA which might be more "global" and long-lived.

\section{Calcium influx and stimulation of exocytosis}

In excitable cells, such as beta cells, voltage-dependent $\mathrm{Ca}^{2+}$ channels (VDCC) are the predominant gate- 
keepers for cellular $\mathrm{Ca}^{2+}$ influx important in many vital cellular processes, including insulin secretion [17]. These channels are hetero-oligomeric protein complexes composed of at least four subunits, $\alpha 1, \beta, \alpha 2, \delta$ [127]. There is ample evidence that L-type VDCC play a pivotal role in beta-cell secretion, although the precise subunit composition of the channels involved and their metabolic modulation are not known [17, 128]. This goal has been complicated by the fact that all types of VDCC, including the two L-type classes $\alpha 1 \mathrm{c}$ and $\alpha 1 \mathrm{~d}$ and four different $\beta$ subunits are expressed in pancreatic beta cells $[46,47,129]$.

The regulated release of insulin from the beta cell seems to utilize a mechanism that is highly conserved across many cell types including neuroendocrine cells [130]. Exocytosis is a sequential and multi-step process involving margination of granules, their docking at the plasma membrane, possible priming mechanisms, membrane fusion and the dissociation and recycling of exocytotic components. The consensus model is termed the soluble NSF-associated protein receptor or SNARE hypothesis where a vesicle-bound protein (V-SNARE) associates with a protein on a target membrane (t-SNARE) forming a complex which brings the secretory vesicle into extremely close approximation with the plasma membrane [130]. The tSNARE proteins are syntaxin (four isoforms) and synaptosomal-associated protein of $25 \mathrm{kD}$ (SNAP-25) (three isoforms), while vesicle-associated membrane protein (VAMP) (three isoforms) is the vesicle-bound protein. The $\mathrm{Ca}^{2+}$ sensitivity of exocytosis is thought to be mediated by another vesicle-associated protein, synaptotagmin, which normally acts as a brake on membrane fusion.

Secretory granules can be divided into those which correspond to a readily releasable pool, which may include both primed and unprimed vesicles, and to a separate reserve pool [131]. The latter granules require mobilization, docking and a "priming" event which could utilize ATP while the former are release competent. Recently, the ready releasable pool has been quantitated by immunologic detection of the docking complex and shown to be responsible for $\mathrm{KCl}$-induced insulin release as well as the first phase of GSIS [132]. Inhibition of GSIS by hexamminecobalt (III) chloride, which was found to act by stabilizing the docking complex, is consistent with this conclusion [133].

\section{Modulation of protein kinase $\mathbf{C}$ isoforms in the beta cell}

There is no doubt that exogenous NEFA increases LCCoA and potentiates GSIS and that this action is physiologically relevant $[25,86,92]$. Therefore, what is missing is a signalling cascade linking changes in LC$\mathrm{CoA}$ to changes in insulin release. $\mathrm{PKC}$ isoforms are
Table 2. Differential regulation of PKC isoform classes

\begin{tabular}{llllll}
\hline & \multicolumn{3}{l}{ CO-FACTORS } & \multirow{2}{*}{ LC-CoA } \\
\cline { 2 - 3 } & & PS & DAG & $\mathrm{Ca}^{2+}$ & \\
\hline Conventional PKC (cPKC) & $\mathrm{X}$ & $\mathrm{X}$ & $\mathrm{X}$ & + \\
Novel PKC (nPK) & $\mathrm{X}$ & $\mathrm{X}$ & & & no action/- \\
Atypical PKC (aPKC) & $\mathrm{X}$ & & & & ++ \\
\hline
\end{tabular}

To date there are 12 known PKC isoforms, of which 7 are expressed in the pancreatic beta cell: $\operatorname{cPKC}(\alpha, \beta \mathrm{II}) ; \operatorname{nPKC}(\delta, \varepsilon$, $\mu)$; $\operatorname{aPKC}(1, \zeta)$. The isoforms are classified based on the linear structure of and co-factor binding to their regulatory domains. The catalytic domains are highly conserved across all isoforms

reasonable candidates for this cascade to either initiate secretion or augment GSIS as they respond to both lipid signals and $\mathrm{Ca}^{2+}[31,134]$. An alternative model could involve modifications of proteins not involving phosphorylation but rather acylation, or a combination of both processes possibly at different points in signal transduction after the generation of LC-CoA [94, 135].

PKC is a family of 11 or 12 isozymes depending on nomenclature, which are divided into three classes, based on structure and co-factor requirements (Table 2). The conventional class (cPKC) requires phosphatidylserine (PS), DAG and $\mathrm{Ca}^{2+}$, while the novel class (nPKC) does not require $\mathrm{Ca}^{2+}$. The atypical class (aPKC) has only a known requirement for an acidic phospholipid such as PS and therefore little is known about its regulation. PKC- $\mu$ can be considered a separate class of kinase as $\mathrm{PKD}$ or a $\mathrm{nPKC}$ isoform having a modified phorbol ester binding site ( $\mathrm{C} 1$ domain) and a putative transmembrane leader sequence. Unlike many enzymes, cPKC and nPKC isozymes require intracellular translocation and targeting to membrane surfaces for their activation [136]. The mechanism of this targeting involves both lipid $(\mathrm{C} 1)$ and $\mathrm{Ca}^{2+}$ binding domains (C2) as well as protein-protein interactions with adaptor molecules contained in the cytosol [136]. The beta cell expresses seven isoforms, PKC- $\alpha$, $\beta \mathrm{II}, \delta, \varepsilon, 1$ and $\zeta$ as well as PKC- $\mu[31,137,138]$. Although the beta cell contains isoforms of most major protein-kinase families; the regulation of the isoforms within a family is similar, except for PKC. This implies that in the case of other kinases, isozymes could provide redundancy for critical processes, whereas in the case of PKC these isoforms could underpin different cellular functions. Thus, it is of considerable interest to determine the physiological determinants of activation for the different PKC isoforms.

The stimulus-secretion coupling of some non-nutrient secretagogues occurs via $\mathrm{PKC}$ in receptor-mediated events linked to phospholipase C [139]. Phospholipase-C activation generates DAG, which translocates and activates PKC isoforms to phosphorylate endogenous substrates. Down-regulation of PKC isoforms by 
chronic activation and the use of inhibitors suggests that $\mathrm{PKC}-\alpha, \beta \mathrm{I} / \beta \mathrm{II}$ and $\varepsilon$ mediate such pathways [140]. In contrast, the role of PKC in glucose-induced insulin secretion is unresolved, with several arguments for and against its involvement [141]. Glucose causes a rise in DAG $[24,30,142]$ and promotes the translocation of PKC- $\alpha$ in the beta cell $[143,144,145]$. This is consistent with the observation that the mass of PKC- $\alpha$ correlates with the ability of phorbol myristate acetate (PMA), a high affinity surrogate for DAG, to stimulate secretion [146]. Therefore, the short-term activation of PKC is thought to be a positive signal for insulin secretion as seen by the effects of either phorbol esters or cell permeant diacylglycerols.

We have recently shown that down-regulation of PKC activity by chronic phorbol ester stimulation led to the differential loss of PKC isoforms as reflected in the loss of $\mathrm{Ca}^{2+}$-dependent PKC activity seen in HIT cells [31]. Overnight exposure to $200 \mathrm{nmol} / \mathrm{l} \mathrm{PMA} \mathrm{re-}$ sulted in the down-regulation of PKC- $\alpha, \beta \mathrm{II}$, and $\varepsilon$ with the masses of PKC- $\delta, \imath, \zeta$ unaltered. Whereas PKC- $\mu$ was not down-regulated, its mass was enriched in a Triton-X100 soluble membrane fraction [31]. After down-regulation, GSIS was not only preserved but enhanced, while the absolute potentiation due to exogenous NEFA did not change [31]. Therefore, the incremental potentiation due to NEFA was reduced by $35 \%$, consistent with the loss of specific PKC isoforms. In line with this result is a report showing the blocking of NEFA-stimulated secretion by inhibitors of cPKC and $\mathrm{nPKC}$ isoforms in perifused rat islets [147]. In addition, we have shown that KCl-induced insulin secretion was also enhanced after PMA downregulation $[140,146])$. This would suggest that an increased sensitivity of exocytosis to $\mathrm{Ca}^{2+}$ and/or an increase in the ready releasable pool of secretory granules was due to an increased vesicle priming or to the prior inhibition of exocytosis. Recent work has shown that the enhanced secretory responses, both basal and stimulated, after PMA-induced down-regulation requires the presence of the phorbol ester in the cell [146]. This implies that DAG could also couple to secretion via either PKC- $\delta$ or $\mu$; however, the data do not exclude involvement of a non-PKC target.

LC-CoA and PA can modulate the activity of different classes of PKC and their interaction with DAG and PS. PA has been shown to strongly augment the stimulation of PKC- $\zeta$ by PS [148]. Phosphatidylserine alone caused a slight stimulation above background $(6 \% \pm 2, p<0.01)$ while the combination of PS and PA caused a sixfold increase above the activity seen with PS alone. In addition, several long-chain acyl-CoA esters in combination with PS also stimulated cPKC activity fourfold and aPKC activity eightfold above PS alone [31]. Short-chain acyl-CoA esters were without effect in the presence of PS or PS plus DAG.

Previous studies have documented effects of PA [148] or PI-3,4,5-trisphosphate [149], in activating
PKC- $\zeta$. Recent evidence shows that the lipid-dependent kinase, PDK-1, activates PKC- $\zeta$ in a PI-3,4,5 $\mathrm{P}_{3}$ dependent fashion by phosphorylation of threonine410 of its activation loop [150]. Thus, a possibility still to be explored is that new regulators of islet PKC play a role in the potentiation of GSIS by NEFA.

\section{Lipid-dependent translocation of PKC}

A study in islets examining the effect of palmitate on beta-cell physiology showed that it did not inhibit the $\mathrm{K}_{\mathrm{ATP}}$-channel, or alter the membrane potential or the ATP:ADP ratio but modestly increased intracellular $\mathrm{Ca}^{2+}$ [78]. This rise in intracellular $\mathrm{Ca}^{2+}$ only increased secretion when glucose was increased, in keeping with action of the fatty acid as an incretin. A follow-up study showed that palmitate did not increase phospholipid turnover but did translocate PKC activity to a membrane fraction, only in the presence of stimulating glucose [43]. Significantly, blocking the metabolism of this NEFA (activation to LC-CoA) also blocked its ability to translocate PKC activity and stimulate insulin secretion. This suggests that either the LC-CoA or its esterification into a complex lipid such as DAG or PA was required for this effect.

Translocation of both PKC- $\alpha$ and $\zeta$ has been directly shown in response to glucose or glucose plus NEFA in islets and clonal beta cells [31, 144]. In the presence of glucose, exogenous oleate rapidly ( $3 \mathrm{~min}$ ) enriched a total particulate fraction with $\mathrm{PKC}-\zeta$, consistent with its involvement in potentiated secretion [31]. NEFA addition to many cell types, including platelets, hepatocytes and myocytes, have shown PKC isoform translocation [151]. A recent study has shown through confocal microscopy that different NEFA translocated fluorescent-tagged PKC- $\gamma$ and $\varepsilon$ in COS-7 and CHO$\mathrm{K} 1$ cells [152]. The targeting was rapid and reversible and varied depending on the NEFA species used. The activity of cPKC has been enhanced by palmitoylation through increased targeting to cell membranes [135]. Of interest, PKC isoform translocation was much slower and not reversible when NEFA were combined with cell permeant diacylglycerols. In addition, this group found that each PKC isoform had a unique translocation pattern that depended on the stimulus involved, suggesting that this mechanism confers specificity to the cellular response.

\section{Modulation of secretory granule transport and exocytosis}

Both protein kinases $\mathrm{C}$ and $\mathrm{A}$ seem to modulate granule pools in neurons and various neuroendocrine cells including beta cells, but perhaps by different mechanisms $[153,154,155,156]$. A study examining the synergism between PKC and PKA in the potentiation 
of GSIS showed that cAMP caused bulk movement of insulin granules whereas only phorbol esters increased the number of marginated granules $[156,157]$. Stimulation of this margination was lost after PKC downregulation, suggesting that $\mathrm{PKC}-\alpha, \beta \mathrm{II}$ or $\varepsilon$ might be involved. In addition, cAMP concentrations in the beta cell are increased with PKC activation probably at the level of adenylyl cyclase phosphorylation and activation [158]. This suggests the existence of cross-talk between PKC signalling and the generation of cAMP, a well-known potentiator of GSIS [159].

Phorbol esters are known to activate PKC and stimulate secretion in permeabilized beta cells where $\mathrm{Ca}^{2+}$ is clamped by extracellular chelation, suggesting a direct action of phosphorylation on exocytosis [160]. A number of proteins associated with the exocytotic machinery are substrates for PKC. The association of SNAP-25 or Munc-18 with syntaxin is lessened after their phosphorylation by PKC [161, 162]. Unphosphorylated Munc-18 binds to syntaxin and prevents its association with VAMP or SNAP-25, but after phosphorylation these interactions are facilitated, as is vesicle docking. The association of myristoylated alanine-rich C-kinase substrate (MARCKS) with the plasma membrane is dependent on its phosphorylation state [163]. Unphosphorylated it cross-links actin filaments at the cell periphery preventing the docking of secretory vesicles. However, phorbol-ester induced phosphorylation results in the translocation of MARCKS into the cytosol, rearrangement of cortical actin and increased vesicle docking [164]. In addition, the action of a phosphorylated cytosolic protein, P145, implicated in the $\mathrm{Ca}^{2+}$-dependent catecholamine secretion was restored in PKC-deficient permeabilized PC12 cells after the addition of brain PKC [165]. Finally, recent evidence suggests that the L-type calcium channel is functionally coupled to or in close proximity with SNARE proteins in the beta cell $[166,167]$ and that channel function might be either augmented or inhibited by PKC phosphorylation depending on the channel's subunit composition [168, 169, 170].

Given that a phorbol ester would activate cPKC and $\mathrm{nPKC}$ isoforms, it is not clear yet which isoforms modulate the marginated pool of granules. It is not known whether aPKC isoforms have a similar effect on this pool, but this would be consistent with the observation that LC-CoA appears to stimulate both cPKC and aPKC isoforms [31]. The mix of DAG and LC-CoA esters at a membrane site (plasma or granule) might determine which PKC isoforms are stimulated and to what extent. In mixed micelle assays palmitoylCoA stimulated cPKC and aPKC activities whereas it had no effect on nPKC activity [31]. In contrast, in the presence of PS plus DAG, CoA esters of oleate and myristate partially inhibited $\mathrm{nPKC}$, while stimulating aPKC activity [31]. Although the mechanism of this inhibition is not known, it was independent of DAG concentration.
Several steps in the transport of secretory granules or exocytosis machinery are candidates for modification by acylation using long-chain fatty acids. The presence of palmitoyl-CoA seems to accelerate membrane fusion processes in a reconstituted system of vesicular trafficking as it increased budding of Golgi transport vesicles from donor membranes and their fusion to acceptor cisternae $[171,172]$. This action was suggested to result from protein acylation, as a nonhydrolyzable analogue of LC-CoA inhibits fusion of vesicles to Golgi surfaces. However, LC-CoA does not appear to act as a fusagen for secretory vesicles and the plasma membrane. Therefore, the observations that NEFA stimulate insulin secretion after PKC and PKA activation [52] and that in permeabilized beta cells short-term addition of LC-CoA initiates secretion [69] suggest that acylation modulates exocytosis directly.

While the core SNARE proteins syntaxin and synaptobrevin (VAMP) are thought to be associated with membranes via their hydrophobic C-termini, SNAP25 is potentially palmitoylated at four centrally-located residues, which seems to stabilize its association with the plasma membrane [173]. However, it is not clear whether palmitoylation is required for the initial membrane targeting or only after membrane attachment of newly synthesized SNAP-25 is achieved via its association with syntaxin [174]. This latter point and the fact that palmitoylation could play a role in the proper dissociation of the core complex before membrane fusion [175] are consistent with the requirement for a functional secretory pathway in detecting in vivo acylation [176]. In addition, VAMP expressed in PC12 cells was also shown to be palmitoylated [177]. Accessory proteins, such as the $\mathrm{Ca}^{2+}$ sensing protein synaptotagmin and cysteine string protein are known to be acylated in situ as well [175, 178]. The acylation of the $\beta$-subunit of the L-type channel or the PKC isoform itself has been shown to enhance their function and thereby could comprise other avenues for the regulation of exocytosis by NEFA $[135,179]$.

Therefore, a net increase in cytosolic LC-CoA due to beta-cell stimulation by either exogenous NEFA or increased beta cell lipolysis would be a positive effector of insulin secretion, hypothesized to be mediated by changes in the distal steps in stimulus-secretion coupling.

\section{Conclusion}

The preceding sections have indicated the important roles of NEFA, LC-CoA and their esterified derivatives in affecting insulin secretion in both normal and pathological states, and the likely involvement of the various members of the PKC family of lipid-modulated protein kinases. As mentioned at the outset, the 
rapid increase in obesity is the risk factor most likely to be driving the epidemic of Type 2 diabetes worldwide, and the connection between obesity and diabetes is most likely to be the high concentrations of circulating lipids and tissue triglyceride deposits, leading to increased cellular sources of NEFA. The development of Type 2 diabetes requires both beta-cell insufficiency and insulin resistance in target tissues, such that glucose disposal into muscle is retarded and hepatic glucose output is inadequately restricted. In the beta cell, chronically increased fatty acids produce inappropriate hypersecretion at low glucose concentrations, and an insufficient response to increased glucose, while in the target tissues, increased fatty acids cause insulin resistance. Interestingly, in the adipocyte, which is also an insulin-sensitive tissue, the antilipolytic effect of insulin is much less affected, so that the basal hypersecretion of the beta cell could further promote lipid storage and obesity [180]. This predicted link has been observed experimentally when inhibition of hypersecretion by diazoxide treatment was shown to enhance the weight loss observed in obese hyperinsulinaemic adults [181].

Sources. This review is based on relevant articles published in English during the period of 1990 to the present (2003) including seminal contributions prior to this. PubMed searches were done using various combinations of the following terms: fatty acid, islets of Langerhans, insulin secretion, protein kinase C, exocytosis, acylation and metabolism.

Acknowledgements. The authors would like to thank Dr. K. Tornheim for critical reading of the manuscript and to the National Institutes of Health (grants DK35914, DK63356 and DK46200) for support. Due to the journal's limit on the total number of references some pertinent references have been omitted in this review.

\section{References}

1. Zimmet P, Alberti KG, Shaw J (2001) Global and societal implications of the diabetes epidemic. Nature 414:782-787

2. Fraze E, Donner CC, Swislocki AL, Chiou YA, Chen YD, Reaven GM (1985) Ambient plasma free fatty acid concentrations in noninsulin-dependent diabetes mellitus: evidence for insulin resistance. J Clin Endocrinol Metab 61:807-811

3. Lewis B, Mancini M, Mattock M, Chait A, Fraser TR (1972) Plasma triglyceride and fatty acid metabolism in diabetes mellitus. Eur J Clin Invest 2:445-453

4. McGarry JD (1992) What if Minkowski had been ageusic? An alternative angle on diabetes. Science 258:766-770

5. Coleman DL (1978) Obese and diabetes: two mutant genes causing diabetes-obesity syndromes in mice. Diabetologia 14:141-148

6. Porte D Jr (1991) Banting lecture 1990. Beta-cells in type II diabetes mellitus. Diabetes 40:166-180

7. Arch JR, Ainsworth AT, Cawthorne MA et al. (1984) Atypical $\beta$-adrenoceptor on brown adipocytes as target for antiobesity drugs. Nature 309:163-165
8. Bloom JD, Dutia MD, Johnson BD et al. (1992) Disodium (R,R)-5-[2-[[2-(3-chlorophenyl)-2-hydroxyethyl]-amino] propyl]-1,3-benzodioxole-2,2-dicarboxylate (CL 316,243). A potent beta-adrenergic agonist virtually specific for $\beta 3$ receptors. A promising antidiabetic and antiobesity agent. J Med Chem 35:3081-3084

9. Holloway BR, Howe R, Rao BS, Stribling D (1992) ICI D7114: a novel selective adrenoceptor agonist of brown fat and thermogenesis. Am J Clin Nutr 55:262S-264S

10. Yoshida T (1992) The antidiabetic $\beta 3$-adrenoceptor agonist BRL 26830A works by release of endogenous insulin. Am J Clin Nutr 55:237S-241S

11. Himms-Hagen J, Cui J, Danforth E Jr et al. (1994) Effect of CL-316,243, a thermogenic $\beta 3$-agonist, on energy balance and brown and white adipose tissues in rats. Am J Physiol 266:R1371-R1382

12. Susulic VS, Frederich RC, Lawitts J et al. (1995) Targeted disruption of the $\beta 3$-adrenergic receptor gene. J Biol Chem 270:29483-29492

13. Grujic D, Susulic VS, Harper ME et al. (1997) $\beta 3$-adrenergic receptors on white and brown adipocytes mediate beta3-selective agonist-induced effects on energy expenditure, insulin secretion, and food intake. A study using transgenic and gene knockout mice. J Biol Chem 272: 17686-17693

14. Hedeskov CJ (1980) Mechanism of glucose-induced insulin secretion. Physiol Rev 60:442-509

15. Ashcroft FM, Harrison DE, Ashcroft SJ (1984) Glucose induces closure of single potassium channels in isolated rat pancreatic $\beta$-cells. Nature 312:446-448

16. Arkhammar P, Nilsson T, Rorsman P, Berggren PO (1987) Inhibition of ATP-regulated $\mathrm{K}^{+}$channels precedes depolarization-induced increase in cytoplasmic free $\mathrm{Ca}^{2+}$ concentration in pancreatic $\beta$-cells. J Biol Chem 262:5448-5454

17. Prentki M, Matschinsky FM (1987) $\mathrm{Ca}^{2+}$, cAMP, and phospholipid-derived messengers in coupling mechanisms of insulin secretion. Physiol Rev 67:1185-1248

18. Turk J, Wolf BA, McDaniel ML (1987) The role of phospholipid-derived mediators including arachidonic acid, its metabolites, and inositoltrisphosphate and of intracellular $\mathrm{Ca}^{2+}$ in glucose-induced insulin secretion by pancreatic islets. Prog Lipid Res 26:125-181

19. Corkey BE, Tornheim K, Deeney JT et al. (1988) Linked oscillations of free $\mathrm{Ca}^{2+}$ and the ATP/ADP ratio in permeabilized RINm5F insulinoma cells supplemented with a glycolyzing cell-free muscle extract. J Biol Chem 263:4254-4258

20. Corkey BE, Deeney JT, Glennon MC, Matschinsky FM, Prentki M (1988) Regulation of steady-state free $\mathrm{Ca}^{2+}$ levels by the ATP/ADP ratio and orthophosphate in permeabilized RINm5F insulinoma cells. J Biol Chem 263:42474253

21. Longo EA, Tornheim K, Deeney JT, Varnum BA, Tillotson D, Prentki M, Corkey BE (1991) Oscillations in cytosolic free $\mathrm{Ca}^{2+}$, oxygen consumption, and insulin secretion in glucose-stimulated rat pancreatic islets. J Biol Chem 266: 9314-9319

22. Malaisse WJ, Malaisse-Lagae F, Sener A (1984) Coupling factors in nutrient-induced insulin release. Experientia 40:1035-1043

23. Pralong WF, Bartley C, Wollheim CB (1990) Single islet $\beta$-cell stimulation by nutrients: relationship between pyridine nucleotides, cytosolic $\mathrm{Ca}^{2+}$ and secretion. EMBO J 9:53-60

24. Corkey B, Glennon MC, Chen KS, Deeney JT, Matschinsky FM, Prentki M (1989) A role for malonyl-CoA in glucosestimulated insulin secretion from clonal pancreatic $\beta$-cells. J Biol Chem 264:21608-21612 
25. Prentki M, Vischer S, Glennon MC, Regazzi R, Deeney JT, Corkey BE (1992) Malonyl-CoA and long chain acyl-CoA esters as metabolic coupling factors in nutrient-induced insulin secretion. J Biol Chem 267:5802-5810

26. Chen S, Ogawa A, Ohneda M, Unger RH, Foster DW, McGarry JD (1994) More direct evidence for a malonylCoA-carnitine palmitoyltransferase I interaction as a key event in pancreatic $\beta$-cell signaling. Diabetes 43:878-883

27. Berne $C$ (1975) The metabolism of lipids in mouse pancreatic islets. The biosynthesis of triacylglycerols and phospholipids. Biochem J 152:667-673

28. Berne C (1975) The metabolism of lipids in mouse pancreatic islets. The oxidation of fatty acids and ketone bodies. Biochem J 152:661-666

29. Vara E, Tamarit-Rodriguez J (1986) Glucose stimulation of insulin secretion in islets of fed and starved rats and its dependence on lipid metabolism. Metab Clin Exp 35:266-271

30. Peter-Riesch B, Fathi M, Schlegel W, Wollheim CB (1988) Glucose and carbachol generate 1,2-diacylglycerols by different mechanisms in pancreatic islets. J Clin Invest $81: 1154-1161$

31. Yaney GC, Korchak HM, Corkey BE (2000) Long-chain acyl CoA regulation of protein kinase $\mathrm{C}$ and fatty acid potentiation of glucose-stimulated insulin secretion in clonal $\beta$-cells. Endocrinology 141:1989-1998

32. Prentki M, Corkey BE (1996) Are the $\beta$-cell signaling molecules malonyl-CoA and cytosolic long-chain acyl-CoA implicated in multiple tissue defects of obesity and NIDDM? Diabetes 45:273-283

33. MacDonald MJ (1995) Feasibility of a mitochondrial pyruvate malate shuttle in pancreatic islets. Further implication of cytosolic NADPH in insulin secretion. J Biol Chem 270:20051-20058

34. MacDonald MJ (1993) Estimates of glycolysis, pyruvate (de)carboxylation, pentose phosphate pathway, and methyl succinate metabolism in incapacitated pancreatic islets. Arch Biochem Biophys 305:205-214

35. MacDonald MJ, McKenzie DI, Walker TM, Kaysen JH (1992) Lack of glyconeogenesis in pancreatic islets: expression of gluconeogenic enzyme genes in islets. Horm Metab Res 24:158-160

36. Brun T, Roche E, Assimacopoulos-Jeannet F, Corkey BE, Kim KH, Prentki M (1996) Evidence for an anaplerotic/malonyl-CoA pathway in pancreatic $\beta$-cell nutrient signaling. Diabetes 45:190-198

37. Farfari S, Schulz V, Corkey B, Prentki M (2000) Glucoseregulated anaplerosis and cataplerosis in pancreatic $\beta$-cells: possible implication of a pyruvate/citrate shuttle in insulin secretion. Diabetes 49:718-726

38. Schuit F, De Vos A, Farfari S et al. (1997) Metabolic fate of glucose in purified islet cells. Glucose-regulated anaplerosis in beta cells. J Biol Chem 272:18572-18579

39. MacDonald MJ, Fahien LA (1990) Insulin release in pancreatic islets by a glycolytic and a Krebs cycle intermediate: contrasting patterns of glyceraldehyde phosphate and succinate. Arch Biochem Biophys 279:104-108

40. Maechler P, Kennedy ED, Pozzan T, Wollheim CB (1997) Mitochondrial activation directly triggers the exocytosis of insulin in permeabilized pancreatic $\beta$-cells. EMBO J 16:3833-3841

41. Biden TJ, Taylor KW (1983) Effects of ketone bodies on insulin release and islet-cell metabolism in the rat. Biochem J 212:371-377

42. Malaisse WJ, Malaisse-Lagae F, Rasschaert J et al. (1990) The fuel concept for insulin release: regulation of glucose phosphorylation in pancreatic islets. Biochem Soc Trans 18:107-108
43. Alcazar O, Qiu-yue Z, Gine E, Tamarit-Rodriguez J (1997) Stimulation of islet protein kinase $C$ translocation by palmitate requires metabolism of the fatty acid. Diabetes 46 : 1153-1158

44. Prentki M, Tornheim K, Corkey BE (1997) Signal transduction mechanisms in nutrient-induced insulin secretion. Diabetalogia 40:S32-S41

45. Aguilar-Bryan L, Nichols CG, Wechsler SW et al. (1995) Cloning of the $\beta$-cell high-affinity sulfonylurea receptor: a regulator of insulin secretion. Science 268:423-426

46. Seino S, Chen L, Seino M et al. (1992) Cloning of the $\alpha 1-$ subunit of a voltage-dependent calcium channel expressed in pancreatic beta cells. Proc Natl Acad Sci USA 89:584588

47. Yaney GC, Wheeler MB, Wei X et al. (1992) Cloning of a novel $\alpha 1$-subunit of the voltage-dependent calcium channel from the $\beta$-cell. Mol Endocrinol 6:2143-2152

48. Aizawa T, Sato Y, Ishihara F et al. (1994) ATP-sensitive $\mathrm{K}^{+}$ channel-independent glucose action in rat pancreatic $\beta$-cell. Am J Physiol 266:C622-C627

49. Gembal M, Detimary P, Gilon P, Gao ZY, Henquin JC (1993) Mechanisms by which glucose can control insulin release independently from its action on adenosine triphosphate-sensitive $\mathrm{K}^{+}$channels in mouse B cells. J Clin Invest 91:871-880

50. Komatsu M, Schermerhorn T, Aizawa T, Sharp GW (1995) Glucose stimulation of insulin release in the absence of extracellular $\mathrm{Ca}^{2+}$ and in the absence of any increase in intracellular $\mathrm{Ca}^{2+}$ in rat pancreatic islets. Proc Natl Acad Sci USA 92:10728-10732

51. Jonas J-C, Gilon, P and J-C Henquin (1998) Temporal and quantitative corelations between insulin secretion and stably elevated or oscillatory cytoplasmic $\mathrm{Ca}^{2+}$ in mouse pancreatic $\beta$-cells. Diabetes 47:1266-1273

52. Komatsu M, Sharp GW (1998) Palmitate and myristate selectively mimic the effect of glucose in augmenting insulin release in the absence of extracellular $\mathrm{Ca}^{2+}$. Diabetes 47:352-357

53. Roche E, Farfari S, Witters LA et al. (1998) Long-term Exposure of $\beta$-INS cells to high glucose concentrations increases anaplerosis, and lipogenic gene expression. Diabetes 47:1086-1094

54. Zhang S, Kim KH (1998) Essential role of acetyl-CoA carboxylase in the glucose-induced insulin secretion in a pancreatic $\beta$-cell line. Cell Signal 10:35-42

55. Tornheim K (1997) Are metabolic oscillations responsible for normal oscillatory insulin secretion? Diabetes 46:13751380

56. Gumbiner B, Van Cauter E, Beltz WF et al. (1996) Abnormalities of insulin pulsatility and glucose oscillations during meals in obese noninsulin-dependent diabetic patients: effects of weight reduction. J Clin Endocrinol Metab 81:2061-2068

57. Porksen N, Hollingdal M, Juhl C, Butler P, Veldhuis JD, Schmitz O (2002) Pulsatile insulin secretion: detection, regulation, and role in diabetes. Diabetes 51:S245-S254

58. Nilsson T, Schultz V, Berggren PO, Corkey BE, Tornheim K (1996) Temporal patterns of changes in ATP/ADP ratio, glucose 6-phosphate and cytoplasmic free $\mathrm{Ca}^{2+}$ in glucosestimulated pancreatic beta-cells. Biochem J 314:91-94

59. Deeney JT, Kohler M, Kubik K et al. (2001) Glucose-induced metabolic oscillations parallel those of $\mathrm{Ca}^{2+}$ and insulin release in clonal insulin-secreting cells. A multiwell approach to oscillatory cell behavior. J Biol Chem 276: 36946-36950

60. Civelek VN, Deeney JT, Shalosky NJ et al. (1996) Regulation of $\beta$-cell mitochondrial function: Influence of $\mathrm{Ca}^{2+}$, 
substrate, and ADP on oxygen consumption by permeabilized clonal pancreatic $\beta$-cells. Biochem J 318:615-621

61. Yaney GC, Schultz V, Cunningham BA, Dunaway GA, Corkey BE, Tornheim K (1995) Phosphofructokinase isozymes in pancreatic islets and clonal $\beta$-cells (INS-1). Diabetes 44:1285-1289

62. Civelek VN, Deeney JT, Kubik K, Schultz V, Tornheim K, Corkey BE (1996) Temporal sequence of metabolic and ionic events in glucose-stimulated clonal pancreatic betacells (HIT). Biochem J 315:1015-1019

63. Larsson O, Deeney JT, Bränström R, Berggren PO, Corkey BE (1996) Activation of the ATP-sensitive $\mathrm{K}^{+}$channel by long chain acyl-CoA. A role in modulation of pancreatic $\beta$ cell glucose sensitivity. J Biol Chem 271:10623-10626

64. Branstrom R, Leibiger IB, Leibiger B, Corkey BE, Berggren PO, Larsson O (1998) Long chain coenzyme A esters activate the pore-forming subunit (Kir6. 2) of the ATP-regulated potassium channel. J Biol Chem 273: 31395-31400

65. Bränström R, Corkey BE, Berggren PO, Larsson O (1997) Evidence for a unique long chain acyl-CoA ester binding site on the ATP-regulated potassium channel in mouse pancreatic $\beta$-cells. J Biol Chem 272:17390-17394

66. Gribble FM, Proks P, Corkey BE, Ashcroft FM (1998) Mechanism of cloned ATP-sensitive potassium channel activation by oleoyl-CoA. J Biol Chem 273:26383-26387

67. Malaisse WJ, Best L, Kawazu S, Malaisse-Lagae F, Sener A (1983) The stimulus-secretion coupling of glucose-induced insulin release: fuel metabolism in islets deprived of exogenous nutrient. Arch Biochem Biophys 224:102-110

68. Hellerstrom C (1967) Effects of carbohydrates on the oxygen consumption of isolated pancreatic islets of mice. Endocrinology 81:105-112

69. Deeney JT, Gromada J, Hoy M et al. (2000) Acute stimulation with long chain acyl-CoA enhances exocytosis in insulin-secreting cells (HIT T-15 and NMRI beta-cells). J Biol Chem 275:9363-9368

70. Hamilton JA, Kamp F (1999) How are free fatty acids transported in membranes? Is it by proteins or by free diffusion through the lipids? Diabetes 48:2255-2269

71. Grupping AY, Cnop M, Van Schravendijk CF, Hannaert JC, Van Berkel TJ, Pipeleers DG (1997) Low density lipoprotein binding and uptake by human and rat islet beta cells. Endocrinology 138:4064-4068

72. Cruz WS, Kwon G, Marshall CA, McDaniel ML, Semenkovich CF (2001) Glucose and insulin stimulate heparin-releasable lipoprotein lipase activity in mouse islets and INS-1 cells. A potential link between insulin resistance and $\beta$-cell dysfunction. J Biol Chem 276:1216212168

73. McGarry JD, Sen A, Esser V, Woeltje KF, Weis B, Foster DW (1991) New insights into the mitochondrial carnitine palmitoyltransferase enzyme system. Biochimie 73:77-84

74. Boylan JG, Hamilton JA (1992) Interactions of acyl-coenzyme A with phosphatidylcholine bilayers and serum albumin. Biochemistry 31:557-567

75. Corkey BE, Deeney JT (1990) Acyl CoA regulation of metabolism and signal transduction. Prog Clin Biol Res 321: 217-232

76. Corkey B (1988) Analysis of acyl-coenzyme A esters in biological samples. Methods Enzymol 166:55-70

77. Deeney JT, Tornheim K, Korchak HM, Prentki M, Corkey BE (1992) Acyl-CoA esters modulate intracellular $\mathrm{Ca}^{2+}$ handling by permeabilized clonal pancreatic $\beta$-cells. J Biol Chem 267:19840-19845

78. Warnotte C, Gilon P, Nenquin M, Henquin J-C (1994) Mechanisms of the stimulation of insulin release by satu- rated fatty acids. Astudy of palmiate in mouse $\beta$-cells. Diabetes 43:703-711

79. Warnotte C, Nenquin M, Henquin JC (1999) Unbound rather than total concentration and saturation rather than unsaturation determine the potency of fatty acids on insulin secretion. Mol Cell Endocrinol 153:147-153

80. Gravena C, Mathias PC, Ashcroft SJ (2002) Acute effects of fatty acids on insulin secretion from rat and human islets of Langerhans. J Endocrinol 173:73-80

81. Crespin SR, Greenough WB 3rd, Steinberg D (1969) Stimulation of insulin secretion by infusion of free fatty acids. J Clin Invest 48:1934-1943

82. Paolisso G, Gambardella A, Amato L et al. (1995) Opposite effects of short- and long-term fatty acid infusion on insulin secretion in healthy subjects. Diabetologia 38:1295-1299

83. Tamarit-Rodriguez J, Vara E, Tamarit J (1984) Starvationinduced changes of palmitate metabolism and insulin secretion in isolated rat islets stimulated by glucose. Biochem J 221:317-324

84. Vara E, Fernandez-Martin O, Garcia C, Tamarit-Rodriguez J (1988) Palmitate dependence of insulin secretion, "de novo" phospholipid synthesis and ${ }^{45} \mathrm{Ca}^{2+}$-turnover in glucose stimulated rat islets. Diabetologia 31:687-693

85. Thams P, Capito K (2001) Differential mechanisms of glucose and palmitate in augmentation of insulin secretion in mouse pancreatic islets. Diabetologia 44:738-746

86. Dobbins RL, Chester MW, Stevenson BE, Daniels MB, Stein DT, McGarry JD (1998) A fatty acid-dependent step is critically important for both glucose- and non-glucosestimulated insulin secretion. J Clin Invest 101:2370-2376

87. Ramanadham S, Hsu F, Zhang S, Bohrer A, Ma Z, Turk J (2000) Electrospray ionization mass spectrometric analyses of phospholipids from INS-1 insulinoma cells: comparison to pancreatic islets and effects of fatty acid supplementation on phospholipid composition and insulin secretion. Biochim Biophys Acta 1484:251-266

88. Ramanadham S, Hsu FF, Bohrer A, Ma Z, Turk J (1999) Studies of the role of group VI phospholipase A2 in fatty acid incorporation, phospholipid remodeling, lysophosphatidylcholine generation, and secretagogue-induced arachidonic acid release in pancreatic islets and insulinoma cells. J Biol Chem 274:13915-13927

89. Opara EC, Garfinkel M, Hubbard VS, Burch WM, Akwari OE (1994) Effect of fatty acids on insulin release: role of chain length and degree of unsaturation. Am J Physiol 266:E635-E639

90. Stein DT, Stevenson BE, Chester MW, Basit M, Daniels MB, Turley SD, McGarry JD (1997) The insulinotropic potency of fatty acids is influenced profoundly by their chain length and degree of saturation. J Clin Invest 100:398-403

91. Dobbins RL, Chester MW, Daniels MB, McGarry JD, Stein DT (1998) Circulating fatty acids are essential for efficient glucose-stimulated insulin secretion after prolonged fasting in humans. Diabetes 47:1613-1618

92. Stein DT, Esser V, Stevenson BE et al. (1996) Essentiality of circulating fatty acids for glucose-stimulated insulin secretion in the fasted rat. J Clin Invest 97:2728-2735

93. Roduit R, Masiello P, Wang SP, Li H, Mitchell GA, Prentki M (2001) A role for hormone-sensitive lipase in glucosestimulated insulin secretion: a study in hormone-sensitive lipase-deficient mice. Diabetes 50:1970-1975

94. Yajima H, Komatsu M, Yamada S et al. (2000) Cerulenin, an inhibitor of protein acylation, selectively attenuates nutrient stimulation of insulin release: a study in rat pancreatic islets. Diabetes 49:712-717

95. Sako Y, Grill VE (1990) A 48-hour lipid infusion in the rat time-dependently inhibits glucose-induced insulin secre- 
tion and B cell oxidation through a process likely coupled to fatty acid oxidation. Endocrinology 127:1580-1589

96. Carpentier A, Mittelman SD, Lamarche B, Bergman RN, Giacca A, Lewis GF (1999) Acute enhancement of insulin secretion by FFA in humans is lost with prolonged FFA elevation. Am J Physiol 276:E1055-E1066

97. Dobbins RL, Szczepaniak LS, Myhill J, Tamura Y, Uchino H, Giacca A, McGarry JD (2002) The composition of dietary fat directly influences glucose-stimulated insulin secretion in rats. Diabetes 51:1825-1833

98. Marshall JA, Bessesen DH, Hamman RF (1997) High saturated fat and low starch and fibre are associated with hyperinsulinaemia in a non-diabetic population: the San Luis Valley Diabetes Study. Diabetologia 40:430-438

99. Majumdar S, Rossi MW, Fujiki T et al. (1991) Protein kinase $\mathrm{C}$ isotypes and signaling in neutrophils. Differential substrate specificities of a translocatable calcium- and phospholipid-dependent beta-protein kinase $\mathrm{C}$ and a phospholipid-dependent protein kinase which is inhibited by long chain fatty acyl coenzyme A. J Biol Chem 266: 9285-9294

100. Woldegiorgis G, Yousufzai SY, Shrago E (1982) Studies on the interaction of palmitoyl coenzyme A with the adenine nucleotide translocase. J Biol Chem 257:1478314787

101. Tippett PS, Neet KE (1982) Specific inhibition of glucokinase by long chain acyl coenzymes A below the critical micelle concentration. J Biol Chem 257:12839-12845

102. Brun T, Assimacopoulos-Jeannet F, Corkey BE, Prentki M (1997) Long-chain fatty acids inhibit acetyl-CoA carboxylase gene expression in the pancreatic $\beta$-cell line INS-1. Diabetes 46:393-400

103. Assimacopoulos-Jeannet F, Thumelin S, Roche E, Esser V, McGarry JD, Prentki M (1997) Fatty acids rapidly induce the carnitine palmitoyltransferase I gene in the pancreatic beta-cell line INS-1. J Biol Chem 272:1659-1664

104. Liu YQ, Tornheim K, Leahy JL (1998) Fatty acid-induced beta cell hypersensitivity to glucose. Increased phosphofructokinase activity and lowered glucose-6-phosphate content. J Clin Invest 101:1870-1875

105. Liu YQ, Tornheim K, Leahy JL (1998) Shared biochemical properties of glucotoxicity and lipotoxicity in islets decrease citrate synthase activity and increase phosphofructokinase activity. Diabetes 47:1889-1893

106. Bollheimer LC, Skelly RH, Chester MW, McGarry JD, Rhodes CJ (1998) Chronic exposure to free fatty acid reduces pancreatic beta cell insulin content by increasing basal insulin secretion that is not compensated for by a corresponding increase in proinsulin biosynthesis translation. J Clin Invest 101:1094-1101

107. Gremlich S, Bonny C, Waeber G, Thorens B (1997) Fatty acids decrease IDX-1 expression in rat pancreatic islets and reduce GLUT2, glucokinase, insulin, and somatostatin levels. J Biol Chem 272:30261-30269

108. Bjorklund A, Yaney G, McGarry JD, Weir G (1997) Fatty acids and $\beta$-cell function. Diabetologia 40:B21-B26

109. Mulder H, Holst LS, Svensson H et al. (1999) Hormonesensitive lipase, the rate-limiting enzyme in triglyceride hydrolysis, is expressed and active in $\beta$-cells. Diabetes 48:228-232

110. Winzell MS, Svensson H, Arner P, Ahren B, Holm C (2001) The expression of hormone-sensitive lipase in clonal $\beta$-cells and rat islets is induced by long-term exposure to high glucose. Diabetes 50:2225-2230

111. Holm C, Osterlund T, Laurell H, Contreras JA (2000) Molecular mechanisms regulating hormone-sensitive lipase and lipolysis. Annu Rev Nutr 20:365-393
112. Masiello P, Novelli M, Bombara M et al. (2002) The antilipolytic agent 3,5-dimethylpyrazole inhibits insulin release in response to both nutrient secretagogues and cyclic adenosine monophosphate agonists in isolated rat islets. Metab Clin Exp 51:110-114

113. Yaney GC, Civelek VN, Richard AM et al. (2001) Glucagon-like peptide 1 stimulates lipolysis in clonal pancreatic $\beta$-cells (HIT). Diabetes 50:56-62

114. Cunningham BA, Richard AM, Dillon JS et al. (2003) Glucagon-like peptide 1 and fatty acids amplify pulsatile insulin secretion from perifused rat islets. Biochem $\mathrm{J}$ 369:173-178

115. Haemmerle G, Zimmermann R, Hayn M et al. (2002) Hormone-sensitive lipase deficiency in mice causes diglyceride accumulation in adipose tissue, muscle, and testis. J Biol Chem 277:4806-4815

116. Faergeman NJ, Knudsen J (1997) Role of long-chain fatty acyl-CoA esters in the regulation of metabolism and in cell signalling. Biochem J 323:1-12

117. Metz SA, Dunlop M (1990) Stimulation of insulin release by phospholipase D. A potential role for endogenous phosphatidic acid in pancreatic islet function. Biochem $\mathrm{J}$ 270:427-435

118. Hodgkin MN, Pettitt TR, Martin A, Michell RH, Pemberton AJ, Wakelam MJ (1998) Diacylglycerols and phosphatidates: which molecular species are intracellular messengers? Trends Biochem Sci (TIBS) 23:200-204

119. Goetzl EJ (2001) Pleiotypic mechanisms of cellular responses to biologically active lysophospholipids. Prostaglandins Other Lipid Mediat 64:11-20

120. Eddlestone GT (1995) ATP-sensitive K channel modulation by products of PLA2 action in the insulin-secreting HIT cell line. Am J Physiol 268:C181-C90

121. Baukrowitz T, Fakler B (2000) K(ATP) channels: linker between phospholipid metabolism and excitability. Biochem Pharmacol 60:735-740

122. Severson DL, Hurley B (1984) Inhibition of the hormonesensitive lipase in adipose tissue by long-chain fatty acyl coenzyme A. Lipids 19:134-138

123. Kindmark H, Kohler M, Efendic S, Rorsman P, Larsson O, Berggren PO (1992) Protein kinase C activity affects glucose-induced oscillations in cytoplasmic free $\mathrm{Ca}^{2+}$ in the pancreatic $\beta$-cell. FEBS Lett 303:85-90

124. Lawrie AM, Toescu EC, Gallacher DV (1993) Two different spatiotemporal patterns for $\mathrm{Ca}^{2+}$ oscillations in pancreatic acinar cells: evidence of a role for protein kinase $\mathrm{C}$ in Ins(1,4,5)P3-mediated $\mathrm{Ca}^{2+}$ signalling. Cell Calcium 14:698-710

125. Martin F, Reig JA, Soria B (1995) Secretagogue-induced $\left[\mathrm{Ca}^{2+}\right] \mathrm{i}$ changes in single rat pancreatic islets and correlation with simultaneously measured insulin release. J Mol Endocrinol 15:177-185

126. Nakazaki M, Ishihara H, Kakei M et al. (1998) Repetitive mitochondrial $\mathrm{Ca}^{2+}$ signals synchronize with cytosolic $\mathrm{Ca}^{2+}$ oscillations in the pancreatic $\beta$-cell line, MIN6. Diabetologia 41:279-286

127. Takahashi M, Seagar MJ, Jones JF, Reber BF, Catterall WA (1987) Subunit structure of dihydropyridine-sensitive calcium channels from skeletal muscle. Proc Natl Acad Sci USA 84:5478-5482

128. Satin LS, Tavalin SJ, Kinard TA, Teague J (1995) Contribution of L- and non-L-type calcium channels to voltage-gated calcium current and glucose-dependent insulin secretion in HIT-T15 cells. Endocrinology 136: 4589-4601

129. Ihara Y, Yamada Y, Fujii Y et al. (1995) Molecular diversity and functional characterization of voltage-dependent 
calcium channels (CACN4) expressed in pancreatic betacells. Mol Endocrinol 9:121-130

130. Sollner TH, Rothman JE (1996) Molecular machinery mediating vesicle budding, docking and fusion. Experientia 52:1021-1025

131. Rorsman P, Eliasson L, Renstrom E, Gromada J, Barg S, Gopel S (2000) The cell physiology of biphasic insulin secretion. News Physiol Sci 15:72-77

132. Daniel S, Noda M, Straub SG, Sharp GWG (1999) Identification of the docked granule pool responsible for the first phase of glucose-stimulted insulin secretion. Diabetes 48:1686-1690

133. Tsubamoto Y, Eto K, Noda M et al. (2001) Hexamminecobalt(III) chloride inhibits glucose-induced insulin secretion at the exocytotic process. J Biol Chem 276:29792985

134. Newton AC, Johnson JE (1998) Protein kinase C: a paradigm for regulation of protein function by two membrane-targeting modules. Biochim Biophys Acta 1376: 155-172

135. Ford DA, Horner CC, Gross RW (1998) Protein kinase C acylation by palmitoyl coenzyme A facilitates its translocation to membranes. Biochemistry 37:11953-11961

136. Newton AC (1997) Regulation of protein kinase C. Curr Opin Cell Biol 9:161-167

137. Knutson KL, Hoenig M (1994) Identification and subcellular characterization of protein kinase- $\mathrm{C}$ isoforms in insulinoma beta-cells and whole islets. Endocrinology 135: 881-886

138. Tian YM, Urquidi V, Ashcroft SJ (1996) Protein kinase C in $\beta$-cells: expression of multiple isoforms and involvement in cholinergic stimulation of insulin secretion. Mol Cell Endocrinol 119:185-193

139. Zawalich WS, Zawalich KC (1996) Regulation of insulin secretion by phospholipase C. Am J Physiol 271:E409E416

140. Zawalich WS, Bonnet-Eymard M, Zawalich KC, Yaney GC (1998) Chronic exposure to TPA depletes PKC- $\alpha$ and augments Ca-dependent insulin secretion from cultured rat islets. Am J Physiol 274:C1388-C1396

141. Deeney JT, Cunningham BA, Chheda S et al. (1996) Reversible $\mathrm{Ca}^{2+}$-dependent translocation of protein kinase $\mathrm{C}$ and glucose-induced insulin release. J Biol Chem 271: 18154-18160

142. Wolf BA, Easom RA, McDaniel ML, Turk J (1990) Diacylglycerol synthesis de novo from glucose by pancreatic islets isolated from rats and humans. J Clin Invest 85: 482-490

143. Ganesan S, Calle R, Zawalich K, Smallwood JI, Zawalich WS, Rasmussen H (1990) Glucose-induced translocation of protein kinase $\mathrm{C}$ in rat pancreatic islets. Proc Natl Acad Sci USA 87:9893-9897

144. Ganesan S, Calle R, Zawalich K et al. (1992) Immunocytochemical localization of alpha-protein kinase $\mathrm{C}$ in rat pancreatic $\beta$-cells during glucose-induced insulin secretion. J Cell Biol 119:313-324

145. Yedovitzky M, Mochly-Rosen D, Johnson JA et al. (1997) Translocation inhibitors define specificity of protein kinase $\mathrm{C}$ isoenzymes in pancreatic $\beta$-cells. J Biol Chem 272:1417-1420

146. Yaney GC, Fairbanks JM, Deeney JT, Korchak HM, Tornheim K, Corkey BE (2002) Potentiation of insulin secretion by phorbol esters is mediated by PKC- $\alpha$ and nPKC isoforms. Am J Physiol 283:E880-E888

147. Littman ED, Pitchumoni S, Garfinkel MR, Opara EC (2000) Role of protein kinase $C$ isoenzymes in fatty acid stimulation of insulin secretion. Pancreas 20:256-263
148. Limatola C, Schaap D, Moolenaar WH, van Blitterswijk WJ (1994) Phosphatidic acid activation of protein kinase $\mathrm{C}-\zeta$ overexpressed in COS cells: comparison with other protein kinase $\mathrm{C}$ isotypes and other acidic lipids. Biochem J 304:1001-1008

149. Nakanishi H, Brewer KA, Exton JH (1993) Activation of the $\zeta$ isozyme of protein kinase $\mathrm{C}$ by phosphatidylinositol 3,4,5-trisphosphate. J Biol Chem 268:13-16

150. Chou MM, Hou W, Johnson J et al. (1998) Regulation of protein kinase $\mathrm{C} \zeta$ by PI 3-kinase and PDK-1. Curr Biol 8:1069-1077

151. Khan WA, Blobe G, Halpern A et al. (1993) Selective regulation of protein kinase $\mathrm{C}$ isoenzymes by oleic acid in human platelets. J Biol Chem 268:5063-5068

152. Shirai Y, Kashiwagi K, Yagi K, Sakai N, Saito N (1998) Distinct effects of fatty acids on translocation of $\gamma$ - and $\varepsilon$ subspecies of protein kinase C. J Cell Biol 143:511-521

153. Gillis KD, Mossner R, Neher E (1996) Protein kinase C enhances exocytosis from chromaffin cells by increasing the size of the readily releasable pool of secretory granules. Neuron 16:1209-1220

154. Stevens CF, Sullivan JM (1998) Regulation of the readily releasable vesicle pool by protein kinase C. Neuron 21: 885-893

155. Chen YA, Duvvuri V, Schulman H, Scheller RH (1999) Calmodulin and protein kinase $\mathrm{C}$ increase $\mathrm{Ca}^{2+}$-stimulated secretion by modulating membrane-attached exocytic machinery. J Biol Chem 274:26469-26476

156. Yu W, Niwa T, Fukasawa T et al. (2000) Synergism of protein kinase $\mathrm{A}$, protein kinase $\mathrm{C}$, and myosin light-chain kinase in the secretory cascade of the pancreatic $\beta$-cell. Diabetes 49:945-952

157. Hisatomi M, Hidaka H, Niki I (1996) $\mathrm{Ca}^{2+} /$ calmodulin and cyclic 3,5' adenosine monophosphate control movement of secretory granules through protein phosphorylation/dephosphorylation in the pancreatic $\beta$-cell. Endocrinology 137:4644-4649

158. Tian Y, Laychock SG (2001) Protein kinase C and calcium regulation of adenylyl cyclase in isolated rat pancreatic islets. Diabetes 50:2505-2513

159. Sharp GW (1979) The adenylate cyclase-cyclic AMP system in islets of Langerhans and its role in the control of insulin release. Diabetologia 16:287-296

160. Regazzi R, Li G, Ullrich S, Jaggi C, Wollheim CB (1989) Different requirements for protein kinase $\mathrm{C}$ activation and $\mathrm{Ca}^{2+}$-independent insulin secretion in response to guanine nucleotides. Endogenously generated diacylglycerol requires elevated $\mathrm{Ca}^{2+}$ for kinase $\mathrm{C}$ insertion into membranes. J Biol Chem 264:9939-9944

161. Fujita Y, Sasaki T, Fukui K et al. (1996) Phosphorylation of Munc-18/n-Sec1/rbSec1 by protein kinase C: its implication in regulating the interaction of Munc-18/nSec1/rbSec1 with syntaxin. J Biol Chem 271:7265-7268

162. Shimazaki Y, Nishiki T, Omori A et al. (1996) Phosphorylation of 25-kDa synaptosome-associated protein. Possible involvement in protein kinase $\mathrm{C}$-mediated regulation of neurotransmitter release. J Biol Chem 271:14548-14553

163. Hartwig JH, Thelen M, Rosen A, Jammey PA, Nairn AC, Aderem A (1992) MARCKS is an actin filament crosslinking protein regulated by PKC and calcium-calmodulin. Nature 356:618-622

164. Vitale ML, Seward EP, Trifaro JM (1995) Chromaffin cell cortical actin network dynamics control the size of the release-ready vesicle pool and the initial rate of exocytosis. Neuron 14:353-363

165. Nishizaki T, Walent JH, Kowalchyk JA, Martin TF (1992) A key role for a $145-\mathrm{kDa}$ cytosolic protein in the stimula- 
tion of $\mathrm{Ca}^{2+}$-dependent secretion by protein kinase C. J Biol Chem 267:23972-23981

166. Wiser O, Trus M, Hernandez A et al. (1999) The voltage sensitive Lc-type $\mathrm{Ca}^{2+}$ channel is functionally coupled to the exocytotic machinery. Proc Natl Acad Sci USA 96:248-253

167. Yang SN, Larsson O, Branstrom R et al. (1999) Syntaxin 1 interacts with the $\mathrm{L}(\mathrm{D})$ subtype of voltage-gated $\mathrm{Ca}^{2+}$ channels in pancreatic $\beta$-cells. Proc Natl Acad Sci USA 96:10164-10169

168. Arkhammar P, Juntti BL, Larsson O et al. (1994) Protein kinase $\mathrm{C}$ modulates the insulin secretory process by maintaining a proper function of the beta-cell voltage-activated $\mathrm{Ca}^{2+}$ channels. J Biol Chem 269:2743-2749

169. Yang J, Tsien RW (1993) Enhancement of N- and L-type calcium channel currents by protein kinase $\mathrm{C}$ in frog sympathetic neurons. Neuron 10:127-136

170. McHugh D, Sharp EM, Scheuer T, Catterall WA (2000) Inhibition of cardiac L-type calcium channels by protein kinase $\mathrm{C}$ phosphorylation of two sites in the N-terminal domain. Proc Natl Acad Sci USA 97:12334-12338

171. Pfanner N, Orci L, Glick BS et al. (1989) Fatty acyl-coenzyme A is required for budding of transport vesicles from Golgi cisternae. Cell 59:95-102

172. Pfanner N, Glick BS, Arden SR, Rothman JE (1990) Fatty acylation promotes fusion of transport vesicles with Golgi cisternae. J Cell Biol 110:955-961

173. Gonelle-Gispert C, Molinete M, Halban PA, Sadoul K (2000) Membrane localization and biological activity of SNAP-25 cysteine mutants in insulin-secreting cells. J Cell Sci 113:3197-3205
174. Vogel K, Cabaniols JP, Roche PA (2000) Targeting of SNAP-25 to membranes is mediated by its association with the target SNARE syntaxin. J Biol Chem 275:29592965

175. Washbourne P, Cansino V, Mathews JR, Graham M, Burgoyne RD, Wilson MC (2001) Cysteine residues of SNAP-25 are required for SNARE disassembly and exocytosis, but not for membrane targeting. Biochem J 357:625-634

176. Gonzalo S, Linder ME (1998) SNAP-25 palmitoylation and plasma membrane targeting require a functional secretory pathway. Mol Biol Cell 9:585-597

177. Veit M, Becher A, Ahnert-Hilger G (2000) Synaptobrevin 2 is palmitoylated in synaptic vesicles prepared from adult, but not from embryonic brain. Mol Cell Neurosci 15:408-416

178. Veit M, Sollner TH, Rothman JE (1996) Multiple palmitoylation of synaptotagmin and the t-SNARE SNAP-25. FEBS Lett 385:119-123

179. Chien AJ, Gao T, Perez-Reyes E, Hosey MM (1998) Membrane targeting of L-type calcium channels. Role of palmitoylation in the subcellular localization of the $\beta 2 \mathrm{a}$ subunit. J Biol Chem 273:23590-23597

180. Kahn BB, Flier JS (2000) Obesity and insulin resistance. J Clin Invest 106:473-481

181. Alemzadeh R, Langley G, Upchurch L, Smith P, Slonim AE (1998) Beneficial effect of diazoxide in obese hyperinsulinemic adults. J Clin Endocrinol Metab 83:19111915 